University at Buffalo School of Law

Digital Commons @ University at Buffalo School of Law

The Docket

Law Journals

4-24-2019

\title{
The Time In Between: A Response to A Theory of Civil Problem- Solving Courts
}

Daniel M. Coble

Richland County Magistrate Court, South Carolina

Follow this and additional works at: https://digitalcommons.law.buffalo.edu/the_docket

\section{Recommended Citation}

Daniel M. Coble, The Time In Between: A Response to A Theory of Civil Problem-Solving Courts, 67 (2019).

Available at: https://digitalcommons.law.buffalo.edu/the_docket/7

C) ${ }_{\text {COPYRIGHT }}^{\mathrm{N}}$

This Article is brought to you for free and open access by the Law Journals at Digital Commons @ University at Buffalo School of Law. It has been accepted for inclusion in The Docket by an authorized administrator of Digital Commons @ University at Buffalo School of Law. For more information, please contact lawscholar@buffalo.edu. 


\title{
Buffalo Law Review THE DOCKET
}

$\begin{array}{lll}\text { VOLUME } 67 & \text { APRIL } 2019 & \text { NUMBER } 1\end{array}$

\section{The Time In Between: A Response to A Theory of Civil Problem-Solving Courts}

\author{
DANIEL M. COBLE $\dagger$
}

\begin{abstract}
As small claims courts grow in numbers and popularity, more issues are beginning to rise to the surface. These issues stem from a lack of understanding of the process, not following the court's procedural rules, and many others revolving around pro se litigants. As criminal courts begin to shift how they treat the underlying issues of defendants, so are the ideas for how to handle civil litigants. Most of the solutions proposed for solving civil courts' issues are admirable and likely to succeed. However, as a magistrate judge and former prosecutor who worked closely with South Carolina's first homeless court, I believe that we need to implement two solutions before the long-term plans can be realized: enforcing current contract law through the lens of pro se relaxation, and the application of homeless court principles.
\end{abstract}

\section{INTRODUCTION}

In a recent New York University Law Review article, Professor Jessica K. Steinberg wrote a compelling and much

\footnotetext{
$\dagger$ Daniel M. Coble is the associate chief magistrate judge for Richland County, South Carolina. Prior to his appointment as a magistrate judge, he worked as a state prosecutor and as the prosecutor in charge of the state's first homeless court. Special thanks to George Cauthen and many others for their work in establishing this court.
} 
needed proposal for addressing the significant issues found in small claims court. ${ }^{1}$ Professor Steinberg makes a persuasive argument that small claims courts need to develop new methods to address disparities that arise from two commonly adjudicated case-types: rental housing and consumer debt. ${ }^{2}$ Steinberg's article lays the foundation for why the courts need to develop these new methods by first explaining in a thorough and detailed discussion why there is an actual problem in small claims courts. ${ }^{3}$ She then explains three structural changes that could be made to these courts to help alleviate the issues. ${ }^{4}$ These structural changes are not created out of thin air, but rather, have evolved from alternative drug courts. ${ }^{5}$ In her conclusion, Steinberg address several criticisms she foresees with her plan of change. ${ }^{6}$ While I agree with her assessment of the situation, as well as the need for change, reality dictates that before a substantial and structural reform of these courts, judges and legal professionals should first look to a middle ground to begin the process of change. I propose two reforms for the time between the present and implementation: enforcing current contract law through the lens of pro se relaxation and the application of homeless court principles.

\section{The Perils of Small Claims Courts}

Professor Steinberg correctly points out that courts are burdened with dealing with social problems that are not easily handled within the confines of our legal system. ${ }^{7}$

1. Jessica K. Steinberg, A Theory of Civil Problem-Solving Courts, 93 N.Y.U. L. REV. 1579 (2018).

2. Id. at 1582 .

3. Id. at $1591-1604$.

4. Id. at $1604-31$.

5. Id. at $1582,1585-91$.

6. See id. at 1624-31.

7. Id. at 1591 ("However, much like the criminal courts, the civil courts also confront a number of entrenched social problems that conventional adjudication has proven powerless to address."). 
Historically, it is the criminal side of the law that has seen the rapid rise of alternative courts. ${ }^{8}$ However, as small claims courts continue to grow, more Americans are beginning to find their case called in this venue. Steinberg is precise in her assessment of the two most adjudicated cases in the civil court: rental agreements and consumer debt. ${ }^{9}$

\section{A. Landlord-Tenant Disputes}

It has long been the goal of the United States to provide adequate housing for its citizens. ${ }^{10}$ However, as urban populations expand and major cities grow, the market has become tighter and more expensive. ${ }^{11}$ No matter which town or city one looks to, landlord-tenant issues are sure to be lurking nearby. ${ }^{12}$

8. Office of Justice Programs, Nat'l. Inst. Justice, Specialized Courts, NAT'L INsT. JUsT. (modified May 30, 2018), https://www.nij.gov/topics/courts/pages /specialized-courts.aspx (reporting over 1,300 specialized courts to help criminal defendants as of June 2015).

9. Steinberg, supra note 1, at 1591; see also Colleen F. Shanahan \& Anna E. Carpenter, Simplified Courts Can't Solve Inequality, 148 DaEdalus 128, 129 n.10 (2018) (noting that housing disputes and consumer debt issues doubled in New York State).

10. 42 U.S.C. $§ 1441$ (2012) ("The Congress declares that the general welfare and security of the Nation and the health and living standards of its people require housing production and related community development sufficient to remedy the serious housing shortage, the elimination of substandard and other inadequate housing through the clearance of slums and blighted areas, and the realization as soon as feasible of the goal of a decent home and a suitable living environment for every American family, thus contributing to the development and redevelopment of communities and to the advancement of the growth, wealth, and security of the Nation.").

11. US house prices are going to rise at twice the speed of inflation and pay: Reuters poll, CNBC (updated Jun. 6, 2018, 11:43 AM), https://www.cnbc.com/ 2018/06/06/us-house-prices-are-going-to-rise-at-twice-the-speed-of-inflation-andpay-reuters-poll.html (reporting that approximately $80 \%$ of polled analysists agreed "the already tight supply of affordable homes in the United States will either stay the same or fall from here over the next 12 months.").

12. See, e.g., Emily Badger \& Guoctrung Bui, In 83 Million Eviction Records, a Sweeping and Intimate New Look at Housing in America, N.Y. Times: TheUpshot (Apr. 7, 2018), https://www.nytimes.com/interactive/2018/04/07 /upshot/millions-of-eviction-records-a-sweeping-new-look-at-housing-inamerica.html. 


\section{B. Consumer Debt}

The second legal issue that fills the dockets of local courts are debts that individuals accrue from a myriad of sources. Whether that be car loans, payday lending, or credit card debt that has been bought by a debt collector, consumers often find themselves in front of a judge explaining why they did not keep up with the payments or why they did not understand the exorbitant interest rates. While Steinberg addresses consumer debt and tenant disputes similarly, I believe that the consumer debt has the greater potential to effect everyday citizens and have a net drag on the economy. ${ }^{13}$ Consumer debt is also shifting in how creditors come into contact with potential creditees. It is not uncommon for credit lenders to mail checks to individuals that allow them to immediately cash them in at their local banks. These mailed out checks often have lengthy contract paperwork attached explaining the interest rates and the terms that come with accepting the loan. ${ }^{14}$ It must also be noted though that payday lenders are necessary at times, and effective when providing a direct source of funding on a short term basis that would otherwise not be available.

\section{Structural Failings}

With these two subjects in mind, Steinberg explains why our court system has structural failings when it comes to civil adjudication. Her first point would be hard for any judge or judicial appointee to disagree with: a lack of attorneys representing parties. In both consumer debt and landlord

13. Steinberg, supra note 1 , at 1594 ("The rate of debt collection litigation is subject to rapid growth in times of economic volatility.").

14. Tyler Durden, “Godfather of Of Payday Lending” Stripped Of \$64 Million, Sentenced To 14 Years, ZEROHEDGE (July 10, 2018, 4:55 P.M.) https:/www.zerohedge.com/news/2018-07-10/godfather-payday-lending-stripped -64-million-sentenced-14-years ("Hallinan's case calls into question the legality of business tactics engaged in by predatory lenders across the country-such as Mariner Finance, a subsidiary of former Treasury Secretary Tim Geithner's private equity firm Warburg Pincus."). 
tenant cases, it is rare that the party who is subject to either the debt or eviction is represented by legal counsel. ${ }^{15}$ Without counsel, it is difficult for pro se litigants to not only prepare for their court case, but also to even understand how the judicial process works. At the outset, this leads to several negative outcomes for unrepresented parties-but one in particular: default. By not understanding the rules of civil procedure, it is not uncommon for parties to fail to respond to claims within the proscribed amount of days to avoid default. ${ }^{16}$

Steinberg's next two structural failings of small claims court, large dockets, and "capture" by corporate interests, seem to be more of a symptom rather than a cause. While her article does make a compelling case that high-volume dockets and corporate interests have a negative effect on these court systems, I believe that small claims courts' primary purpose are for these very reasons. By having courts that can effectively and efficiently handle a large number of cases, defendants and plaintiffs alike are allowed to present their case and have their day in court. However, when parties are not represented by counsel and effectively not afforded a day in court, these symptoms rear their ugly head and present the problems that Steinberg so clearly articulates.

\section{Fixing SMall Claims Court Now}

Based on her experience with drug courts, and in particular the Housing Conditions Court, Steinberg explains in depth and detail several methods to create an alternative

15. Steinberg, supra note 1, at 1596 ("In rental housing and consumer debt cases, low rates of attorney representation are particularly problematic for two reasons. First, representation rates for tenants and consumers are among the lowest of all groups in the civil justice system.").

16. See Fed. R. Civ. P. 12(a)(1)(A)-(B) (establishing the timeframes in which a federal civil Defendant must serve an answer to a complaint, counterclaim, or crossclaim.). 
court for civil adjudication. ${ }^{17}$

The framework that Steinberg proposes for fixing these structural problems are admirable and will hopefully be implemented in the future. However, judicial systems take time to develop and these processes can span years if not decades. So what do we do in the meantime? It is with that understanding in mind that I propose two methods to fill the void. First, enforcing current contract law through the lens of pro se relaxation. This method gives judges the power to ensure that pro se litigants (whether plaintiff or defendant) have their day in court. Second, implement the principles found in homeless courts. The substance of these principles are the same as most drug courts and other alternative courts, however, their procedure sets them apart from other alternative courts, and allows for easier and quicker implementation with a smaller financial footprint.

\section{A. Pro Se Relaxation}

All cases that arrive in small claims court still have the same legal requirements as other cases: contract law, tort law, landlord tenant, etc. A plaintiff seeking to enforce a contract for a debt owed still must prove the elements of a contract. This includes proving that an actual contract exists, offer and acceptance, competency, writing, and more. How does this help pro se litigants? Take the example of the unsolicited checks mailed to consumers. Assume Company Y mails a check made payable to John Roberts for $\$ 5,000$. The back of the check clearly states that the act of cashing in the check is acceptance of the terms of the contract and binds the person to those terms. Assume the terms are contained on a separate page. Well it is clear that John Roberts has accepted and entered into a contract by cashing the check. It would be hard for him to argue that he did not read the back of the check which contained the terms. However, what about the accompanying paperwork? Assume that the paperwork went 
into more details, such as the interest rate of $50 \%$, as well as mandatory arbitration. When plaintiff appears at the civil case attempting to collect not only the original $\$ 5,000$, but also the interest accrued, how does the plaintiff prove that the defendant was aware of the terms on the following pages - especially if plaintiff does not have signed copies of those pages? Further, if those terms are considered to be severed from the contract now, then does the defendant still owe the $50 \%$ interest rate that has accrued?

While this hypothetical presents arguments that an attorney (or an eager $3 \mathrm{~L}$ ) would make, does one really expect a pro se litigant to spot these issues, much less understand them? That is why it is important that a "relaxation of the rules" standard apply. Whether this is judicially or statutorily created, relaxing of the rules in small claims court gives power to the judge. This rule not only allows the judge to sua sponte raise issues that otherwise might not be brought up, it gives the judge the freedom to raise them without the fear or trepidation of having a higher court issue an unflattering opinion demanding the judge to stay in his or her lane. Several jurisdictions currently apply a relaxation of the rules of evidence in small claims court. ${ }^{18}$ The purpose of doing so allows for a more efficient and fair trial process.

Why shouldn't we extend the relaxation to certain rules of civil procedure for small claims court? There are actually several good reasons to be wary of relaxing the rules of civil

18. See N.J. R. EvID. 101, available at https://www.njcourts.gov /attorneys/assets/evidence/evidence1.pdf?c=MyT ("These rules of evidence shall apply in all proceedings, civil or criminal, conducted by or under the supervision of a court. Except as provided by paragraph (a)(1) of this rule, these rules may be relaxed in the following instances to admit relevant and trustworthy evidence in the interest of justice: (A) actions within the cognizance of the Small Claims Section of the Special Civil Part of the Superior Court, Law Division, and the Small Claims Division of the Tax Court whether or not the action was instituted in a Small Claims Section or Division.”); S.C. R. MAG. CT. 13(a) available at https://www.sccourts.org/courtReg/displayRule.cfm?ruleID=13.0\&subRuleID=\& ruleType=MAG ("Trials should be conducted in an informal manner and the South Carolina Rules of Evidence shall apply but shall be relaxed in the interest of justice. ..."). 
procedure, especially if taken too far. Rules are a core part of our judicial system so that parties can know what to expect. If some of the rules are applied unevenly then not only do parties suffer from a lack of due process, but our system suffers from a lack of predictability. Courts can become extremely inefficient and even worse, lose litigants' trust, if litigants believe that the system will treat them differently based on which judge is hearing the case and the discretion that particular judge uses when relaxing the rules.

However, while these concerns should be taken seriously and with utmost caution in application, I still believe that it would be a benefit to all parties involved because it would actually add more predictability. If a plaintiff consumer credit business knows that a litigant is pro se, then it is more likely that the litigant will not be aware of the rules of court and thus not raise legal issues that are relevant to the case. However, if a plaintiff creditor knows that the litigant is represented by a competent attorney, then they will at least expect that the rules of court will be properly followed. By having a judge enforce the rules on behalf of a pro se litigant (to a limited extent), then the plaintiff creditor can always expect the same outcome: the rules will likely be followed.

\section{B. Homeless Court Principles}

The second reform that could be implemented before Steinberg's framework is complete is creating a homelesscourt system within the jurisdiction at the county or city level. Homeless court is an alternative court that was created in the 1980s in San Diego, California. ${ }^{19}$ What makes this type of court unique from other alternative courts is the process by which it works. A typical alternative court usually involves a defendant being charged with a crime, enrolling in the court, completing several goals to address his or her underlying issues, and ultimately having the underlying

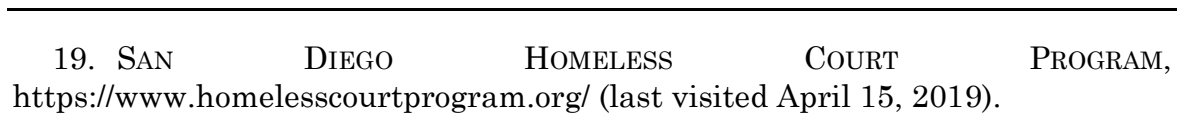


charge dismissed or reduced. ${ }^{20}$ These type of alternative courts do an excellent job of addressing and solving the underlying issue that is causing the defendant to commit some crime. However, these courts take time and resources to implement. A drug court often requires a defendant, prosecutor, defense attorney, judge, probation officers, and many organizations to come together over a lengthy period of time to ensure that the defendant is completing his or her assigned requirements. While this is absolutely a positive goal, it also requires time and resources to come together. Establishing alternative courts can take long periods of time to ensure that all parties are in agreement that they will participate and also to ensure that there is an available source of funds for the court. ${ }^{21}$

The homeless court process is essentially the inverse of a drug court. Defendants, who have accrued old tickets or warrants while they were homeless, wish to have those old fines, fees, or warrants cleared out. ${ }^{22}$ Defendants must first get involved with an approved homeless service provider. They must prove to that provider that they have transitioned or are transitioning out of a homeless lifestyle. This can be shown by attendance of Alcoholic Anonymous meetings,

20. See, e.g., Steven R. Binder, The Homeless Court Program: Taking the Court to the Streets, 65 FED. PROB. J. 14, 15 (2001).

21. See id. at 15-16.

22. See generally Coal. for the Homeless, Homeless Court Details, HomelessHouston.org (last visited Apr. 19, 2019), http://www.homelesshouston.org/homeless-court/homeless-court-details/ ("With alternative sentencing, [Homeless Court] gives 'credit for time served' for the participant's accomplishments in shelter activities. These activities include: life skills; chemical dependency or [Alcoholics Anonymous/Narcotics Anonymous] meetings; computer and literacy classes; training or searching for employment; medical care (physical and mental); counseling; and volunteer work. These activities replace the traditional court sentence options of fines, public service work, or custody.”); Claudia Lopez, Nat'l Ctr. for State Courts, Homeless Courts, NCSC.org (last visited Apr. 19, 2019), https://www.ncsc.org/sitecore /content/microsites/trends/home/Monthly-Trends-Articles/2017/Homeless-

Courts.aspx\#1 ("The sentence normally imposed to satisfy outstanding fines, fees, and warrants includes community service and participation in an approved transitional care program.”). 
community service, job training, employment or many other methods. The service provider then recommends a defendant to the court for either approval or rejection. If the court approves, then the defendant usually has his old fines, fees, or warrants cleared.

Homeless court principles would work better as a placeholder until a drug court framework could be established for two reasons. First, the application of these principles have minimal costs. The defendant has to do the leg-work before approval, and this work is usually done in concert with an already-established service provider. Secondly, this method of inverse procedure reduces the risk of public backlash. Alternative courts are built, among other things, on trust. The prosecutor must trust that the people who use alternative courts are in need of addressing underlying issues and not taking advantage of an opportunity. Defense attorneys and public defenders must trust that their clients will be afforded an opportunity to better themselves and receive a deserved award upon completion. The trust that goes into these courts gives elected and public officials the authority to fund and operate the courts. By having the availability of homeless court procedures, elected and public officials lessen the exposure to risk of public backlash. The defendant has already completed what is required of them and has begun or completed their transition back into society. All the court has to do is confirm the defendant's status or completion with the service provider and give the defendant credit for his or her work.

Obviously, consumer credit companies are not in the business of the public good, but like any capitalistic enterprise, they have to comport with basic economics. So how do courts motivate private companies who are plaintiffs in civil settings to follow principles set out above? A simple method involves requiring more mediation of cases. Courts could initially apply the first method described in this response: relaxation of the rules. This would take a fair and 
judicious approach to pro se litigants who might not have properly complied with the rules. The court could then allow the case, if both parties consent, to go to mediation to resolve the issue of the debt. The mediation would be conducted by an independent mediator and any agreement would need to be approved by the judge. Judges could encourage both parties to resolve the debt through payment plans or other means that are proper for both parties. In accepting or rejecting the mediation agreements, the judge could take into account any improvements the defendant has made in his or her financial standing since defaulting on the original debt.

The mediation agreements would benefit both plaintiff and defendant. Plaintiffs would have a greater chance of recouping some of the debt, while defendants would be able to arrange affordable payment plans and clear out old debts. Another part of the mediation plan would be a requirement that the defendant continue to make timely payments as well as attend financial literacy classes. These are merely general ideas to get the conversation started on alleviating debts between parties.

\section{CONCLUSION}

Professor Steinberg presents a clear portrayal of the status of small claims courts in the United States. I agree with not only her assessment of the current situation, but also that we need to provide a new framework on how to address these issues. However, before this admirable framework can be fully implemented, our judicial system needs to focus on the time in between. By relaxing certain court rules and following homeless court principles, courts could help begin the process and lay the foundation for the framework that Professor Steinberg has laid out. 